Geology, Geophysics \& Environment • 2012 • Vol. 38 • No. $1 \bullet 83-92$

http://dx.doi.org/10.7494/geol.2012.38.1.83

\title{
POMIARY DEFORMACJI REJONU STROPOWEJ PÓŁKI OCHRONNEJ NAD POLEM NR 1 W KOPALNI SOLI KLODAWA
}

\section{Deformation measurements of the roof protective zone over field no. 1 in Kłodawa Salt Mine}

\author{
Józef BIENIASZ ${ }^{1}$, Waldemar WOJNAR ${ }^{1}$ \\ \& Jolanta MARCOLA-SADOWSKA ${ }^{2}$
}

\author{
${ }^{1}$ Ośrodek Badawczo-Rozwojowy Górnictwa Surowców Chemicznych „Chemkop”; \\ ul. Wybickiego 7, 31-261 Kraków; e-mail: wwoj@chemkop.pl \\ ${ }^{2}$ Kopalnia Soli „KŁODAWA” SA; al. 1000-lecia 2, 62-650 Kłodawa; \\ e-mail: jmarcola@sol-klodawa.com.pl
}

\begin{abstract}
Treść: Stropowa półka ochronna o grubości $150 \mathrm{~m}$ nad polem nr 1 jest istotnym elementem bezpieczeństwa eksploatacji w kopalni Kłodawa. Pole eksploatowano w latach 1958-1985 na głębokościach 450-600 m. Obserwacje sieci niwelacyjnej na poziomie 450 rozpoczęto w 1962. Po 2005 roku uzupełniono sieć pomiarów niwelacyjnych i dołączono obserwacje konwergencyjne w sześciu komorach najwyższego poziomu (poziom 475). W 2010 r. rozpoczęto pomiary przemieszczeń poziomych na linii pomiarowej prostopadłej do dłuższej osi pola $\mathrm{nr}$ 1. Zainstalowano dwa stanowiska reperów wgłębnych poza granicą wpływów poeksploatacyjnych jako repery nawiązania sieci lokalnej. Pomiary niwelacyjne w latach 2006-2010 wykazały szybkość osiadań nad centrum pola ok. $-3 \mathrm{~mm} / \mathrm{rok}$, kilkakrotnie mniejszą niż w trakcie wybierania pola. Wyniki pięcioletnich obserwacji konwergencyjnych pokazują powolne, jednostajne zaciskanie komór pod półką ochronną ze średnią szybkością ok. $-5 \mathrm{~mm} / \mathrm{rok}$. Uzyskano pierwsze wyniki pomiarów przemieszczeń poziomych.
\end{abstract}

Słowa kluczowe: deformacje, filar ochronny, niwelacja, konwergencja wyrobisk, pomiary długości

\begin{abstract}
Roof protective zone over field no. 1 in Kłodawa is the essential unit of safety of exploitation in salt mine. Field no. 1 was exploited from 1958 to 1985 on depths from $450 \mathrm{~m}$ to $600 \mathrm{~m}$. Levelling observations on horizon 450 over field no. 1 was begun in 1962. From 2005 levelling was modified and news observations were added. In six chambers excavations of the highest horizon 475 to start measurements of convergence. From 2010 start measurements of horizontal dislocations. On horizon 450 two deep-seated levelling marks out of border of mine influences were installed. The new levelling measurements on 2006-2010 showed to accumulate subsiding trough with speed of vertical deformations about $-3 \mathrm{~mm} / \mathrm{year}$. Results of five years of convergence observation show slow, monotonous the tightening with average the vertical speed about $-5 \mathrm{~mm} / \mathrm{year}$.
\end{abstract}

Key words: mining protective zone, post-exploitation deformation, leveling, convergence and length measurements 


\section{WSTĘP}

Bezpieczne prowadzenie eksploatacji w wysadowych kopalniach soli wymaga zazwyczaj pozostawienia nienaruszonych calizn w górotworze w celu ochrony strefy eksploatacji przed zagrożeniami naturalnymi, głównie zagrożeniem wodnym. Calizny te to filary ochronne, do których należą też stropowe półki ochronne nad przestrzenią eksploatacji w złożu. Jak istotna jest funkcja stropowej półki ochronnej i jak groźny jest brak rozpoznania wzajemnych relacji pomiędzy stanem deformacji a sytuacją hydrogeologiczną w tym fragmencie górotworu, pokazało katastrofalne zatopienie kopalni w Wapnie w 1977 roku. W konkluzji ustaleń komisji Wyższego Urzędu Górniczego powołanej do wyjaśnienia przyczyn tej katastrofy górniczej stwierdzono fakt niedostatecznego rozpoznania budowy półki ochronnej (zwierciadła solnego), co w połączeniu z błędami eksploatacyjnymi doprowadziło do katastrofalnego zatopienia kopalni wodami, które przerwały półkę ochronną.

W kopalni Kłodawa nad polem nr 1 eksploatującym w latach 1958-1985 systemem komorowo-filarowym sól białą na głębokościach 450-600 m pozostawiono solną półkę ochronną. Grubość półki określana przy projektowaniu eksploatacji na 200 m została po ekspertyzie specjalistów Akademii Górniczo-Hutniczej ustalona w 1958 roku na 150 m. Stropowa półka ochronna łącznie z filarem brzeżnym osłania strefę eksploatacji w polu nr 1 przed zagrożeniem wodnym i jednocześnie ogranicza wpływy eksploatacji na nadległy górotwór i powierzchnię terenu. Ten kluczowy dla bezpieczeństwa eksploatacji fragment górotworu jest obiektem niezwykle trudnym, jeśli chodzi o możliwość wszelkich bezpośrednich pomiarów mających na celu poznanie i kontrolę jego stanu deformacji. Wynika to z faktu, że z wyrobisk dostępna jest jedynie niewielka przestrzeń spągowej części półki ochronnej, a cały pozostały masyw skalny półki jest niedostępny do bezpośrednich obserwacji. W przypadku pola nr $1 \mathrm{z}$ wyrobisk najpłytszego poziomu 450 dostępne jest jedynie ok. $20 \%$ całego obszaru wpływów na tym horyzoncie (Fig. 1). Specyficzne, nachylone ułożenie strefy eksploatacji w polu nr 1 sprawia, że ponad połowa strefy wpływów na poziomie 450 (łącznie z lokalnym centrum niecki osiadań) położona jest poza granicą wysadu w obszarze zupełnie niedostępnym do obserwacji. Z tego względu ważne jest wykorzystanie każdej możliwości pomiaru zjawisk deformacyjnych w wyrobiskach górotworu solnego.

\section{DOTYCHCZASOWE POMIARY DEFORMACJI}

Typowym pomiarem rejestrującym deformacje wnętrza górotworu, w tym spągu półki ochronnej jest niwelacja sieci znaków w wyrobiskach położonych przy stropie eksploatacji. W Kłodawie obserwacje reperów na najwyższym poziomie (poziom 450) nad polem nr 1 rozpoczęto w 1962 roku w ramach cyklicznych pomiarów dołowej sieci niwelacyjnej. Sieć niwelacyjną założono i rozpoczęto jej cykliczne obserwacje bezpośrednio po rozpoczęciu eksploatacji, dzięki temu pomiarami uchwycono pierwszą fazę rozwijających się deformacji poeksploatacyjnych, tj. przemieszczeń pionowych. Typowe dołowe znaki wysokościowe tej sieci (metalowe bolce) osadzano płytko $(10-15 \mathrm{~cm})$ w ociosach chodników. Dodatkowo nad polem $\mathrm{nr} 1$ założono wydzieloną sieć obserwacyjną w celu rejestracji przemieszczeń pionowych, której specjalne punkty obserwacyjne stabilizowane były równie płytko w spągu chodników (Fig. 1). 


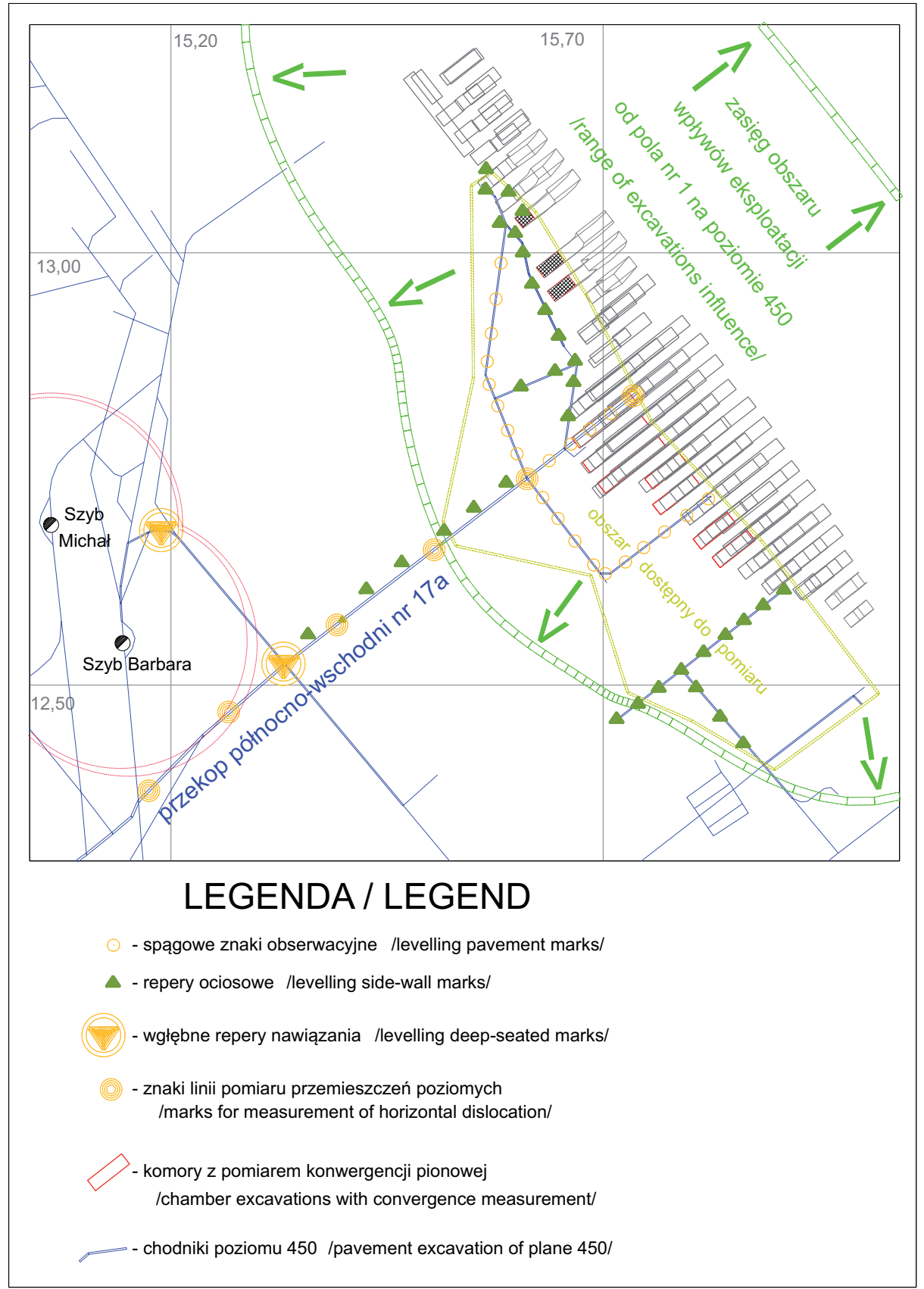

Fig. 1. Schemat kompleksowych pomiarów deformacji rejonu stropowej półki ochronnej nad polem nr 1

Fig. 1. Surveys of protectiv ceiling zone over the field no. 1 in Kłodawa 
Pomiary sieci punktów obserwacyjnych metodą niwelacji geometrycznej wykonywane początkowo w cyklu rocznym, a potem mniej regularnie pozwoliły na uchwycenie obniżeń rejonu spągu półki ochronnej. Analizując wyniki cyklicznych pomiarów niwelacyjnych, stwierdzono formowanie się wewnątrz górotworu nad polem nr 1 lokalnej niecki obniżeń z szybkością osiadań w rejonie jej centrum o wartości ponad -10 mm/rok w okresie eksploatacji pola. Uchwycono też zasięg niecki w kierunku wnętrza wysadu, prostopadłym do rozciągłości pola, charakteryzujący się w tym okresie kątem zasięgu wpływów głównych (parametr teorii wpływów) w przedziale między $40^{\circ}$ a $45^{\circ}$. Największymi mankamentami w analizie wyników obserwacji niwelacyjnych uzyskanych z tej sieci były znaczne ruchy własne znaków wynikające z ich płytkiej stabilizacji w caliźnie oraz ich uszkodzenia i zniszczenia. Wraz z upływem czasu okazywało się, że niektóre repery ociosowe zostały zastabilizowane na odspajających się fragmentach calizny (tzw. łatach), a repery spągowe były uszkadzane, naruszane lub niszczone np. podczas remontu lub przebudowy torowiska. Powodowało to trudności w uchwyceniu reprezentatywnych dla danego rejonu przemieszczeń pionowych i poprawnej interpretacji tego zjawiska na większym obszarze. Drugi czynnik negatywnie wpływający na wartość obserwacji niwelacyjnych sieci dołowej to długie ciągi nawiązania do stałych reperów poza granicą wpływów poeksploatacyjnych. Oznaczało to dużą pracochłonność cyklicznie wykonywanych pomiarów oraz podatność na typowe, sumujące się w długich ciągach, błędy niwelacji geometrycznej. Wpływy tych czynników zaburzały obraz mierzonego zjawiska. Mimo tych niedostatków cykliczne pomiary niwelacyjne sieci dołowej przez wiele lat były jedynym miarodajnym źródłem informacji pozwalającym oszacować stan przemieszczeń pionowych wnętrza górotworu na styku strefy eksploatacji i calizny półki ochronnej.

Oprócz kopalnianych pomiarów niwelacyjnych OBR Chemkop od 1978 r. prowadził obserwacje konwergencji komór i destrukcji filarów międzykomorowych oraz półek międzypoziomowych w pionie komór ks4 na wszystkich poziomach eksploatacji w polu nr 1. Pomiary te są kontynuowane do chwili obecnej, pomimo zakończenia eksploatacji w połowie lat 80 . ubiegłego wieku. Wyniki tych pomiarów wykazały zaciskanie pionowe komory ks4 na poziomie 475 (bezpośrednio pod półką ochronną) z szybkością od $-11 \mathrm{~mm} / \mathrm{rok}$ do $-8 \mathrm{~mm} / \mathrm{rok}$, rozgniatanie filara ks4-ks3/475 w jego przyspągowej części z szybkością $+2 \mathrm{~mm} / \mathrm{rok}$, oraz pęcznienie półki międzypoziomowej ks4 475-500 z szybkością ok. +4 mm/rok (Wojnar \& Bieniasz 2011). Wartości te dotyczą okresu zakończenia eksploatacji w polu nr 1, tj. lat 1984-1991. Od tego czasu obserwowany jest stopniowy, bardzo powolny spadek szybkości zjawisk deformacyjnych w caliznach solnych i pustkach poeksploatacyjnych.

Punktowe obserwacje konwergencji wyrobisk chodnikowych na poziomie 475 (np. w chodniku przyfilarowym w rejonie ks6) prowadzone są także od wielu lat przez służby miernicze kopalni.

\section{NOWE ROZWIĄZANIA POMIAROWE}

Wykorzystując praktyczne doświadczenia kopalni w zakresie dołowych pomiarów niwelacyjnych i doświadczenie OBR Chemkop w pomiarach i analizach deformacji poeksploatacyjnych, zaproponowano i wspólnie zrealizowano rozszerzenie obserwacji w wyrobiskach 
w przystropowej strefie eksploatacji na styku z calizną półki ochronnej. Uzupełniono istniejącą sieć niwelacyjną o linię obserwacyjną, dołączono obserwacje konwergencyjne w komorach znajdujących się bezpośrednio pod półką ochronną oraz rozpoczęto pomiary przemieszczeń poziomych na linii pomiarowej prostopadłej do dłuższej osi pola nr 1 (Bieniasz \& Wojnar 2004). Dzięki połączeniu i skorelowaniu obserwacji przemieszczeń pionowych, przemieszczeń poziomych i konwergencji pustek poeksploatacyjnych uzyskano narzędzie kontroli procesów deformacyjnych rozwijających się na styku strefy eksploatacji i półki ochronnej nad polem nr $1 \mathrm{w}$ formie 3-segmentowego układu pomiarowego (Fig. 1).

\section{Segment obserwacji przemieszczeń pionowych}

W latach 2010-2011 służby miernicze kopalni przeprowadziły przegląd i niezbędne prace konserwacyjne znaków sieci niwelacyjnej na poziomie 450 (odnowienie oznaczeń, skucie wybrzuszeń ociosów) oraz wznowiły jej cykliczne pomiary. Kontynuacja wcześniejszych pomiarów pozwala rejestrować postępujące wykształcanie się w górotworze lokalnej niecki osiadań nad polem nr $1 \mathrm{w}$ spągu półki ochronnej.

Jako uzupełnienie tych przestrzennych pomiarów OBR Chemkop zaproponował założenie linii obserwacji przemieszczeń pionowych w wyjątkowo korzystnie położonym przekopie północno-wschodnim (nr 17a) na poziomie 450. To wyrobisko chodnikowe odchodzi $\mathrm{z}$ rejonu nad centrum pola nr 1, przebiega prostopadle do jego rozciągłości w kierunku SW, aż poza zasięg wpływów eksploatacji od tego pola (Fig. 1). W przekopie tym uzupełniono kopalnianą sieć niwelacyjną o sześć specjalnych znaków stropowych stabilizowanych głębiej (ok. 25 cm) w caliźnie. Część nowych znaków umieszczono nad istniejącymi znakami kopalnianymi, tworząc pary pozwalające zaobserwować lokalne zaciskanie pionowe konturu chodnika i oddzielić ten ruch lokalny od osiadania całego rejonu.

Zmieniono też sposób nawiązania pomiarów niwelacyjnych w tym przekopie, instalując dwa stanowiska reperów wgłębnych w odległości ponad $400 \mathrm{~m}$ od granicy pola i poza prognozowaną granicą wpływów poeksploatacyjnych od całej eksploatacji w wysadzie (Fig. 1). Reper wgłębny tworzy para stalowych prętów zastabilizowana (wklejona) głęboko w otworach odwierconych w stropie i spągu chodnika (głębokość osadzenia 1.9-2.9 m, równa w przybliżeniu wysokości chodnika). Głowica znaku w formie kulistej wyprowadzona jest do przestrzeni chodnika. Zbieżność pionowa takich dwóch reperów mierzona kilkakrotnie w latach 2006-2011 wyniosła sumarycznie odpowiednio $+0.2 \mathrm{~mm} \mathrm{i}-0.3 \mathrm{~mm}$, co przy założeniu symetryczności ruchu stropowego i spągowego oznacza ruch własny spągowego znaku nawiązania bliski zeru (Bieniasz \& Wojnar 2011). Tak niewielki ruch własny znaków nawiązania, poniżej $1 \mathrm{~mm}$ w okresie pięciu lat, świadczy o ich przydatności do lokalnego nawiązywania pomiarów niwelacyjnych założonej linii obserwacyjnej metodą niwelacji geometrycznej. Zarejestrowane w tym samym okresie wzajemne przewyższenie pomiędzy dwoma reperami wgłębnymi wyniosło $1 \mathrm{~mm}$, co potwierdza, że repery usytuowano poza granicą zasięgu wpływów ciągłych od eksploatacji. Względna bliskość reperów nawiązania w stosunku do znaków linii obserwacyjnej wydatnie ograniczyła pracochłonność cyklu pomiarowego oraz zredukowała do minimum poziom możliwych błędów pomiaru nawiązania. 


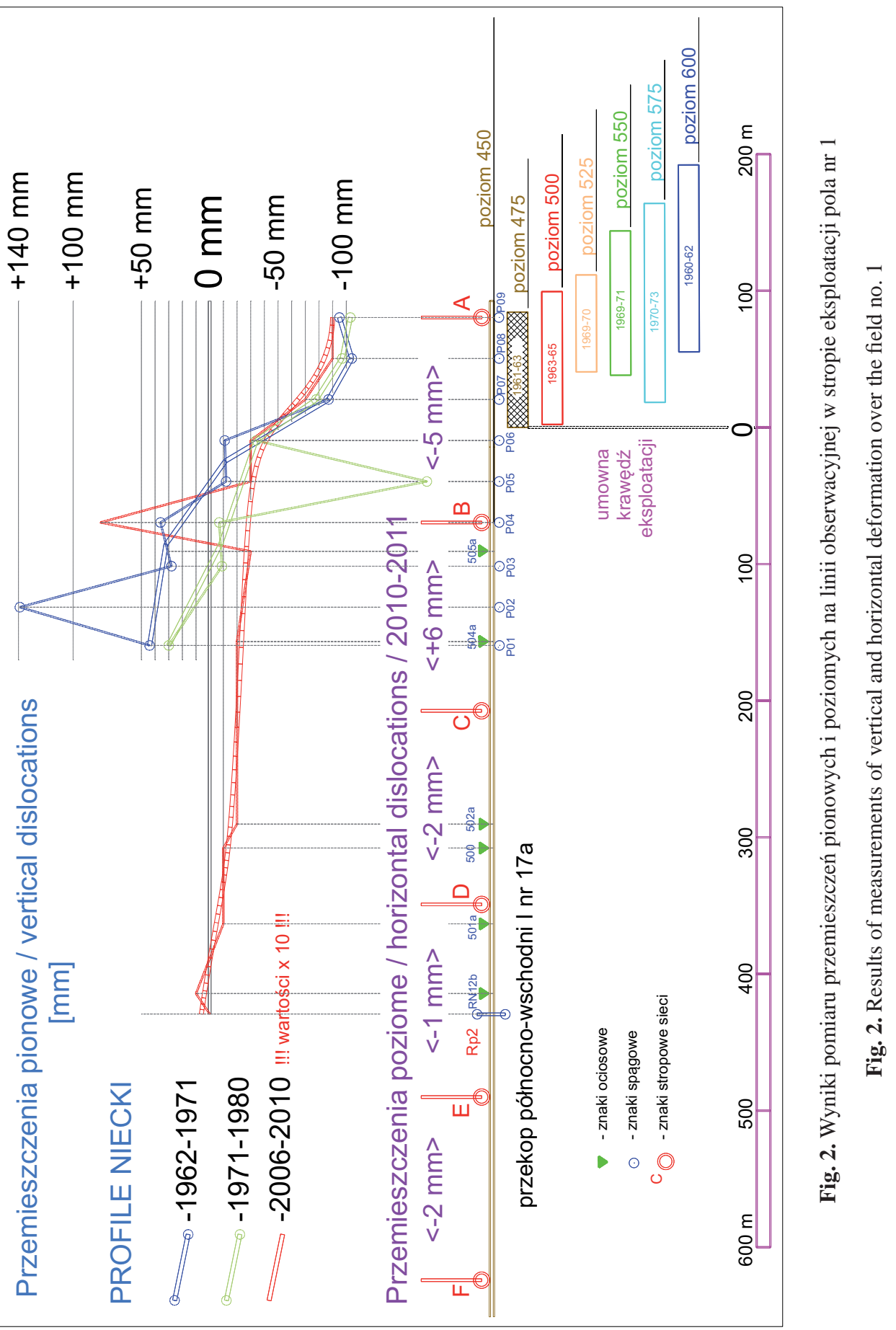


Prowadzone w latach 2006-2010 pomiary niwelacyjne ciągu w przekopie nr 17a i nawiązywane lokalnie do ww. reperów wgłębnych wykazały obniżenie znaków nad komorami centrum pola nr 1 o wartości -9 mm w okresie 3.8 roku (Bieniasz \& Wojnar 2011). Oznacza to, że obecnie, ok. 25 lat po zakończeniu eksploatacji w polu, szybkość osiadań wnętrza górotworu nad centrum pola wynosi ok. $-3 \mathrm{~mm} / \mathrm{rok}$, czyli jest kilkakrotnie mniejsza od rejestrowanej w trakcie wybierania pola. Zestawienie aktualnych i archiwalnych wartości przemieszczeń pionowych zarejestrowanych na linii obserwacyjnej w przekopie nr 17a na tle schematu sytuacji górniczej w górotworze pokazano na zbiorczej figurze 2.

Przedstawione wyniki aktualnych obserwacji niwelacyjnych zostały zebrane w krótkim okresie, ale wydają się świadczyć o zmniejszeniu pierwotnego tempa przemieszczeń pionowych spągu półki ochronnej nad polem nr 1 i stabilizacji osiadań na kilkakrotnie mniejszym poziomie niż w okresie eksploatacji pola.

\section{Segment obserwacji przemieszczeń poziomych}

Nowo zastabilizowane znaki stropowe uzupełniające sieć niwelacyjną w przekopie nr 17a utworzyły linię do obserwacji przemieszczeń poziomych o długości całkowitej ponad $700 \mathrm{~m}$ i długościach boków 133-152 m. Pierwszy pomiar wykonano latem 2010 r. przy użyciu dalmierza elektrooptycznego Elta 55R o dokładności pomiaru $\pm 3 \mathrm{~mm}$. Pomiar wykonywano, centrując instrument pod punktami stropowymi za pomocą pionu optycznego PZO i mierząc odległość z obu końców boku w czterech seriach (Bieniasz \& Wojnar 2011). W kopalni Kłodawa nie mierzono dotychczas przemieszczeń poziomych w wyrobiskach.

Po okresie ok. 13 miesiący w 2011 roku wykonano powtórny pomiar długości pięciu boków linii obserwacyjnej, co pozwoliło obliczyć wartości przemieszczeń poziomych. Wyniki pokazano na zbiorczym rysunku (Fig. 2). Otrzymane wartości przemieszczeń poziomych są niewielkie, porównywalne z wartościami przemieszczeń pionowych i bliskie granicy dokładności pomiaru. Ich rozkład wzdłuż linii obserwacyjnej wykazuje cechy zgodności ze spodziewanym rozkładem przemieszczeń poziomych, wynikającym z teorii wpływów poeksploatacyjnych. Nad komorami pola nr 1 (dno lokalnej niecki) zanotowano skrócenie boku (-5 mm). Nad krawędzią pola eksploatacji zaobserwowano wydłużenie boku (+6 mm), natomiast na obszarze granicy zasięgu oddziaływań i poza nią uzyskano różnice w długościach boków mieszczące się w dokładności pomiaru (-1 mm i -2 mm).

Otrzymane wartości przemieszczeń poziomych należy traktować bardzo ostrożnie, jako że uzyskano je w bardzo krótkim, rocznym interwale pomiarowym. Konieczna jest ich weryfikacja w dłuższym okresie obserwacji, natomiast w chwili obecnej wszelkie dodatkowe interpretacje są niecelowe.

\section{Segment obserwacji konwergencyjnych}

Kolejnym elementem kompleksowych obserwacji zmian w górotworze na styku strefy wyrobisk i półki ochronnej są rozpoczęte w 2005 roku pomiary zaciskania pionowego. Objęto nimi sześć dostępnych komór najwyższego poziomu eksploatacyjnego, tj. poziomu 475, 
pozostałe cztery komory są podsadzone. W cyklu rocznym mierzona jest konwergencja pionowa siedmiu baz w środku przekroju poprzecznego komór. Pomiary wykonywane są w technice opracowanej i od wielu lat stosowanej przez OBR Chemkop w polskich kopalniach soli. Jako urządzenie odczytowe stosowany jest dalmierz laserowy Disto D5 firmy Leica o dokładności pomiaru ok. $1 \mathrm{~mm}$ i opcjonalnej dokładności odczytu odległości do $0.1 \mathrm{~mm}$.

Wyniki pięciu lat cyklicznych, corocznych obserwacji pokazują powolne, jednostajne zaciskanie komór ze średnią szybkością bliską -5 mm/rok (Fig. 3). Wcześniejsze wieloletnie pomiary konwergencji w komorze ks4/475 wykazywały w latach 1984-1991 (okres bezpośrednio po zakończeniu eksploatacji w polu nr 1) szybkość zaciskania pionowego tej komory o wartości ok. $-10 \mathrm{~mm} /$ rok (Wojnar \& Bieniasz 2011). Może to świadczyć o zmniejszeniu się szybkości procesów konwergencyjnych po zakończeniu eksploatacji i ich stabilizacji na niższym poziomie intensywności.

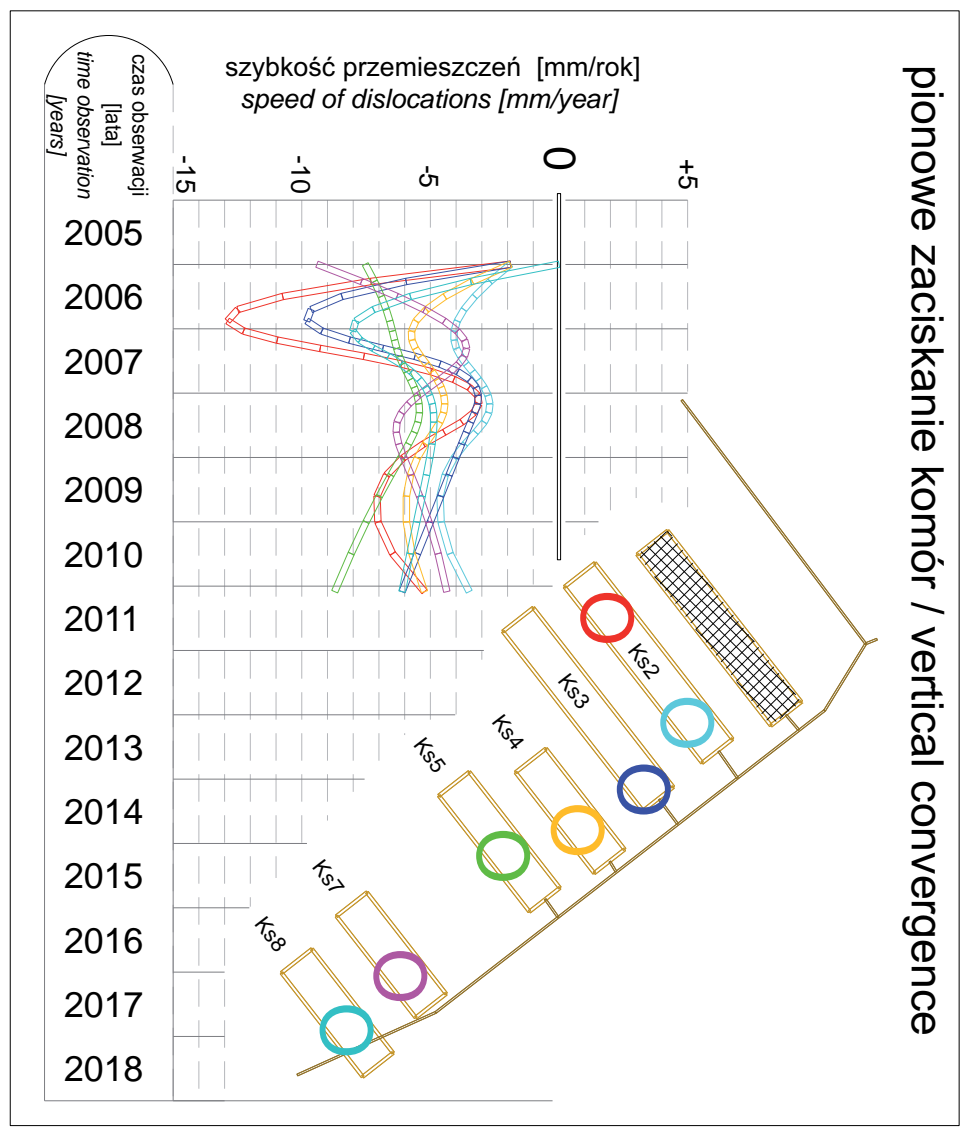

Fig. 3. Wyniki pomiaru pionowego zaciskania komór

Fig. 3. Vertical convergence of chamber excavations 


\section{PODSUMOWANIE}

Calizna półki ochronnej odgrywa istotną rolę w zapewnieniu bezpieczeństwa wodnego wyrobisk kopalnianych i jest obiektem trudnym, jeśli chodzi o możliwość prowadzenia obserwacji zachodzących w niej zjawisk deformacyjnych. Obliguje to do wykorzystania wszelkich możliwości pomiaru tych procesów w wyrobiskach położonych na styku strefy eksploatacji i calizny ochronnej. Zaproponowana i w dużej mierze zrealizowana koncepcja zintegrowanej sieci pomiarowej (Fig. 1), łączącej elementy obserwacji niwelacyjnych, długościowych i konwergencyjnych, umożliwia pomiar rozwoju przemieszczeń przestrzennych w skali globalnej pola eksploatacji oraz przejawów deformacji wytypowanych wyrobisk i calizn w skali lokalnej.

Uzyskane w ciągu kilku lat obserwacji wyniki pomiarowe potwierdziły skuteczność zaproponowanych rozwiązań. Z powodu krótkiego okresu obserwacji nie dają one jeszcze w chwili obecnej pełnego rozeznania intensywności procesów deformacyjnych zachodzących w spągu półki ochronnej oraz tendencji, jakim procesy te podlegają.

Peryferyjnie położone pole nr 1, którego eksploatacji zaprzestano ćwierć wieku temu, jest znakomitym modelem do testowania rozwiązań pomiarowych z dziedziny obserwacji zjawisk poeksploatacyjnych. Wykorzystując opisane powyżej kilkuletnie doświadczenia w obserwacji deformacji ochronnej półki stropowej nad polem nr 1, planuje się realizację podobnego układu pomiarowego wykorzystującego techniki pomiarów niwelacyjnych, konwergencyjnych i długościowych nad znacznie rozleglejszym obszarem eksploatacji w polach nr 2, 3 i 5 .

\section{LITERATURA}

Bieniasz J. \& Wojnar W., 2004. Koncepcja pomiaru stropowej półki ochronnej nad filarowo-komorowym górotworem kopalni soli z wykorzystaniem technik pomiarów konwergencyjnych i niwelacyjnych. Archiwum OBR Chemkop, 1058, 6-8.

Bieniasz J. \& Wojnar W., 2011. Pomiary deformacji stropowej pótki ochronnej nad polem nr 1 w Kopalni Soli Kłodawa z wykorzystaniem technik pomiarów konwergencyjnych, niwelacyjnych i dtugościowych. Archiwum OBR Chemkop, 1097, 3-8.

Wojnar W. \& Bieniasz J., 2011. Wykonanie pomiarów konwergencji komór, filarów i pótek międzypoziomowych oraz chodników w polach eksploatacyjnych $\mathrm{nr}$ 1, 2, 3 i 5 Kopalni Soli Kłodawa. Archiwum OBR Chemkop, 1109, 8-12.

\section{Summary}

The roof protective zone over the field no. 1 in Klodawa is an essential element of safety exploitation in salt mine. Field no. 1 was exploited in the years 1958-1985 on depths from $450 \mathrm{~m}$ to $600 \mathrm{~m}$. The thickness of roof zone is $150 \mathrm{~m}$. Because rock mass space of zone is inaccessibility this measurements of its deformation is difficult. In the case of field no. 1, from the pavement excavation plane 450 is only available about $20 \%$ of the mine influences area. 
The levelling is the typical method for recording the vertical deformations of rock mass. In Kłodawa observations net marks on horizon 450 over field no. 1 began in 1962. Observations showed over field no. 1 the local subsiding trough with speed of vertical deformations about $-10 \mathrm{~mm} /$ year in region of centre.

After 2005 levelling was modified and news observations were added. Convergence measurements included six chambers available on highest horizon 475 . The measurements of the horizontal dislocations started on line perpendicular to the long axis of the field no. 1 .

On horizon 450 was installed two deep-seated levelling marks in distance over $400 \mathrm{~m}$ from field and out of border of mine influences (Fig. 1). The new levelling measurements conducted in 2006-2010 showed accumulate subsiding trough with speed of vertical deformations about $-3 \mathrm{~mm} /$ year. At the present moment the vertical speed of subsiding over centre of field is several times less than that registered 25 years before (Figs 2, 3).

The roof marks, which supplementary levelling net, formed a line to the observations of horizontal displacements length over $700 \mathrm{~m}$ (sides 133-152 m). The first measurement was executed in 2010.

Five years of convergence measurements show slow tightening chambers with an average speed about $-5 \mathrm{~mm} /$ year. The earlier long-term measurements of convergence in the chamber ks4/475 showed between 1984-1991 (the period directly after exploitation in field no. 1) the speed of vertical clamping about $-10 \mathrm{~mm} /$ year.

Using the experience gained in the observation of deformation of the protective roof zone above the field no. 1 is planned to implement a similar measurement system that uses measurement techniques; levelling, convergence and lengths measurements in a much larger area of xploitation over the field no. 2. 